\title{
Age-Related Electrocardiographic Changes in Apparently Healthy Adult Nigerians
}

\author{
Nelson I Oguanobi ${ }^{1 *}$, Charles U Odenigbo ${ }^{2}$, Ogonna C Oguejiofor ${ }^{2}$, Ezechukwu Aniekwensi ${ }^{3}$, Uchenna C \\ Okonkwo ${ }^{4}$, Ukamaka M Odenigbo ${ }^{5}$ and Tobenna Agogbua ${ }^{1}$
}

${ }^{1}$ Department of Internal Medicine, University of Nigeria Teaching Hospital Enugu, Nigeria

${ }^{2}$ Department of Internal Medicine, Nnamdi Azikiwe University Teaching Hospital Nnewi, Nigeria

${ }^{3}$ Department of Medicine, Federal Medical Centre Asaba, Nigeria

${ }^{4}$ Department of Medicine, University College Hospital Calabar, Nigeria

${ }^{5}$ Department of Dietetics, Federal University of Agriculture Umudike, Nigeria

*Corresponding author: Nelson I Oguanobi, Department of Medicine, University of Nigeria Teaching Hospital Enugu, Nigeria.

Received Date: December 19, 2019

Published Date: January 09, 2020

\begin{abstract}
Background: Electrocardiographic abnormalities have been observed in the elderly even in the absence of history of heart disease. However, detailed descriptive data on electrocardiographic changes in healthy elderly individuals are scarce.

Objective: The objective of this study was to evaluate the electrocardiographic parameters and morphology in healthy elderly subjects and to compare these findings with those of healthy young volunteers.

Methods: A total of 66 elderly participants, aged 60 years and above, were recruited from the attendees to the quarterly medical lectures of the Ebreime Foundation for the Elderly, a non Governmental organization. The study was conducted in the medical outpatient clinics of Federal Medical Center, Asaba, Delta State, Nigeria. An electrocardiographic data on a cohort of 62 healthy young volunteers served as controls for the study. All subjects had 12 -lead electrocardiography and background medical assessment with the aid of a questionnaire and then clinically examined to evaluate their cardiovascular status at rest.

Result: The mean age of the elderly subjects was $68.68 \pm 7.92$ (Age range 60 - 91 years). Parameters were compared with those from a cohort of 62 young healthy volunteers aged between 18 and 32 years; mean age $28.37 \pm 5.91$ years.

Electrocardiographic values of P-wave duration, PR interval, and QTc interval were significantly increased in the elderly. Electrocardiographic abnormalities were observed in $83.33 \%$ of the elderly subjects and in $3.23 \%$ of the young subjects. Electrocardiographic abnormality noted include; left ventricular hypertrophy, left atrial enlargement, left axis deviation, non specific ST segment elevation, T-wave inversion and sinus bradycardia.

Conclusion: Our study recorded high prevalence of electrocardiographic abnormalities in asymptomatic apparently healthy elderly subjects. The implication of our findings is that cardiac diseases may present with more subtle symptoms in the elderly. Hence the need for routing evaluation with electrocardiography and other measures for early detection and intervention.
\end{abstract}

Keywords: Age-related; Electrocardiography; Healthy; Elderly

\section{Introduction}

Electrocardiography is a useful non-invasive tool for evaluation of cardiac morphology and function. It has gained universal application in a wide variety of cardiac diseases as well as in the medical fitness test in apparently healthy individuals [1], Morphological abnormalities in the 12-lead electrocardiogram (ECG) have been described in healthy individuals; although most of the studies available were focused on electrocardiographic changes in sports personnel and pre-employment medical evaluation $[2,3,4,5,6]$. However, electrocardiographic abnormalities have been observed in the elderly even in the absence of history of heart disease [7]. This has been attributed to age associated changes in the impulse formation and conduction system, including loss of pacemaker and conducting cell and fibrosis as well as increased incidence of mitral annular and aortic calcification, hypertension 
and coronary artery disease $[1,7]$. The Framingham Heart Study showed that the 2-year incidence of arrhythmia increases sharply with age: $0.5 \%$ among 50-60 years, 4.8\% among 60-69 years and $12.7 \%$ among $70-79$ years [8]. Detailed descriptive data on electrocardiographic changes in healthy elderly individuals are scarce. The objective of this study was to evaluate the electrocardiographic parameters and morphology in healthy elderly subjects and to compare these findings with those of healthy young volunteers. We also sought to examine the effect of various clinical variables on electrocardiographic parameters.

\section{Methods}

A total 219 elderly participants were screened during the study period from the attendees to the quarterly medical lectures of the Ebreime Foundation for the Elderly, a non Governmental organization. Out of these, 66 elderly individuals, aged 60 years and above, were recruited The exclusion criteria for the study were presence of acute illness or history/documentation of chronic illnesses and medications capable of affecting electrocardiogram such as hypertension, diabetes, significant alcohol intake, use of tobacco, drug abuse. The study was conducted in the medical outpatient clinics of Federal Medical Center, Asaba, Delta State, Nigeria. An electrocardiographic data on a cohort of 62 healthy young volunteers made of students, hospital workers as well as members of the local community served as controls for the study. The study was approved by the ethical committees of Federal Medical Center, Asaba, Nigeria Informed consent was obtained from all the participants. All subjects had background medical history assessment with the aid of a questionnaire and then clinically examined to evaluate their cardiovascular status at rest. The weight and height of each subject were recorded, and the surface area determined from a standard formula [9]. Laboratory tests such as serum electrolyte, urea, creatinine, fasting lipid profile (total cholesterol, HDL-cholesterol, LDL, VLDL, triglycerides) and fasting blood glucose were obtained. Resting 12-lead electrocardiography were performed on all subjects using Schiller electrocardiography machine at a paper speed of $25 \mathrm{~mm} / \mathrm{s}$ and standardized at $0.1 \mathrm{mv} / \mathrm{mm}$. A single observer analyzed the electrocardiogram. Measurements of the heart rate, cardiac axis, PR- interval, QRS duration and QTc interval were done in the standard fashion [10]. Heart rate correction of the QT-interval was performed using Bazett's formula (QTc $=\mathrm{QT} / \sqrt{\mathrm{RR}})$ [11]. Standard criteria were followed in the interpretation of morphological electrocardiographic abnormalities $[6,10]$. We considered the ECG as normal in the presence of regular sinus rhythm within a rate range from 60 to 90 beats/min , normal P-wave, PR interval $<200$ $\mathrm{ms}$, normal QRS complex of $<110 \mathrm{~ms}$ duration, normal ST-segment, upright T-waves of $>0.1 \mathrm{mV}$ amplitude in all leads except III, aVR, and $\mathrm{V} 1$, and $\mathrm{QTc}<440 \mathrm{~ms}[10,12]$

\section{Data Analysis}

Data were presented as means \pm standard deviation for continuous variables and as proportions for categorical variables. Comparison of continuous variables between the elderly and the young were made with independent Student's t-test. For discrete variables distribution between groups were compared with Chi- square test and Fishers exact test as appropriate (where an expected cell is less than 5). All statistical analyses were carried out using the Statistical Packages for Social Sciences (SPSS Inc. Chicago Illinois) software version 25.0 and EPi-Info version 3.4. Statistical tests with probability values less than 0.05 were considered statistically significant. Intra observer variability of manual ECG measurements was quantified by blinded and randomly sorted repeat measurements of 30 tracings a month after the original measurements were made. There was no statistically significant intra observer variability.

\section{Result}

Out of the 219 elderly individuals screened during the study period only 66 participants fulfilled the criteria for inclusion as healthy subjects. The mean age of the elderly subjects was 68.68 \pm 7.92 (Age range 60-91 years). Parameters were compared with those from a cohort of 62 young healthy volunteers aged between 18 and 32 years; mean age $28.37 \pm 5.91$ years (Table 1 ). The baseline and anthropometric characteristics are compared in (Table 1). The elderly subjects had significantly higher body mass index compared to the young subjects. Blood pressure indices were comparable in the two groups. However, the younger patients had higher pulse rate (Table 2).

Table 1: Baseline and anthropometric characteristics.

\begin{tabular}{|c|c|c|c|c|}
\hline \multirow{2}{*}{ Parameters } & Young & Elderly & \multirow{2}{*}{ T-Test } & P-Value \\
\cline { 2 - 4 } & Mean (SD) & Mean (SD) & & \\
\hline Age (years) & $28.37(5.91)$ & $68.68(7.92)$ & 32.471 & $<0.0001^{*}$ \\
\hline $\begin{array}{c}\text { Gender } \\
\text { frequency (\%) })\end{array}$ & & & & \\
\hline Male & $31(50)$ & 46 & & \\
\hline Female & $31(50)$ & 20 & 4.386 & $0.362 \mathrm{a}$ \\
\hline Total & 62 & 66 & & \\
\hline Weight(kg) & $67.35(8.37)$ & $66.50(11.40)$ & 0.478 & 0.6333 \\
\hline Height(m) & $1.72(0.07)$ & $1.62(0.13)$ & 5.369 & $<.0001^{*}$ \\
\hline $\begin{array}{c}\text { Body mass index } \\
\left(\text { Kg } / \mathrm{m}^{2}\right)\end{array}$ & $23.87(3.22)$ & $25.38(4.31)$ & 2.234 & $0.0272^{*}$ \\
\hline
\end{tabular}

Key

*Statistically significant

${ }^{a}$ Chi-square

Table 2: Blood pressure indices in the elderly and young.

\begin{tabular}{|c|c|c|c|c|}
\hline Parameters & Elderly & Young & \multirow{2}{*}{ T-Test } & P-Value \\
\cline { 2 - 4 } & Mean (Sd) & Mean (Sd) & \\
\hline $\begin{array}{c}\text { Pulse rate (beat/ } \\
\text { min) }\end{array}$ & $\begin{array}{c}67.76 \\
(13.74)\end{array}$ & $72.13(6.79)$ & 2.258 & $0.0256^{*}$ \\
\hline $\begin{array}{c}\text { Brachial systolic } \\
\text { BP (mmHg) }\end{array}$ & $\begin{array}{c}125.02 \\
(17.27)\end{array}$ & $121.2(8.97)$ & 1.521 & 0.131 \\
\hline $\begin{array}{c}\text { Brachial diastolic } \\
\text { BP (mmHg) }\end{array}$ & $78.88(11.07)$ & $76.88(6.18)$ & 1.264 & 0.2087 \\
\hline $\begin{array}{c}\text { Brachial pulse } \\
\text { pressure (mmHg) }\end{array}$ & $46.14(12.27)$ & $\begin{array}{c}44.31 \\
(10.91)\end{array}$ & 0.89 & 0.3754 \\
\hline $\begin{array}{c}\text { Mean brachial } \\
\text { arterial BP } \\
\text { (mmHg) }\end{array}$ & $94.26(12.16)$ & $91.71(5.47)$ & 1.513 & 0.1327 \\
\hline
\end{tabular}

Key

*Statistically significant 
Table 3: Comparison of electrocardiographic characteristics of the elderly and controls.

\begin{tabular}{|c|c|c|c|c|}
\hline \multirow{2}{*}{ Variables } & \multicolumn{2}{|c|}{ Values (Mean Sd) } & \multirow{2}{*}{ T- Test } & P- Value \\
\cline { 2 - 4 } & Elderly & Young & & \\
\hline $\begin{array}{c}\text { Heart rate } \\
\text { (beat/min) }\end{array}$ & $67.76(13.74)$ & $\begin{array}{c}70.98 \\
(4.24)\end{array}$ & 6.327 & $<.001^{*}$ \\
\hline $\begin{array}{c}\text { P-wave } \\
\text { duration } \\
\text { (msec) }\end{array}$ & $117.42(14.48)$ & $\begin{array}{c}90.30 \\
(14.84)\end{array}$ & 10.463 & $<.0001^{*}$ \\
\hline $\begin{array}{c}\text { PR- interval } \\
\text { (msec) }\end{array}$ & $\begin{array}{c}175.53 \\
(26.70)\end{array}$ & $\begin{array}{c}161.3 \\
(27.13)\end{array}$ & 2.99 & $<.0001^{*}$ \\
\hline $\begin{array}{c}\text { QRS duration } \\
\text { (msec) }\end{array}$ & $84.08(15.19)$ & $\begin{array}{c}81.5 \\
(15.82)\end{array}$ & 0.941 & 0.3484 \\
\hline $\begin{array}{c}\text { QTc- interval } \\
\text { (msec) }\end{array}$ & $411.91(31.13)$ & $\begin{array}{c}393.5 \\
(21.46)\end{array}$ & 3.872 & $<.0002^{*}$ \\
\hline
\end{tabular}

\section{Key}

*Statistically significant

Table 4: Comparison of electrocardiographic characteristics of the elderly and controls.

\begin{tabular}{|c|c|c|c|c|}
\hline \multirow{2}{*}{ Findings } & \multicolumn{2}{|c|}{ Frequency (\%) } & \multirow{2}{*}{$\mathrm{X}$-Square } & \multirow{2}{*}{ P - Value } \\
\hline & Elderly $(n=66)$ & Young(n=62) & & \\
\hline $\begin{array}{l}\text { Left atrial } \\
\text { enlargement }\end{array}$ & $29(43.94)$ & $0(0)$ & 32.76 & $<.0001^{*}$ \\
\hline LVH & $9(13.64)$ & $1(1.7)$ & 4.856 & $.0275^{*}$ \\
\hline RVH & $5(7.58)$ & $0(0)$ & 3.078 & 0.0794 \\
\hline $\begin{array}{c}\text { Left axis } \\
\text { deviation }\end{array}$ & $24(36.36)$ & $0(0)$ & 25.43 & $.0001^{*}$ \\
\hline $\begin{array}{l}\text { 1st degree } \\
\text { AV Block }\end{array}$ & $4(6.06)$ & $0(0)$ & 2.135 & 0.144 \\
\hline $\begin{array}{l}\text { ST-segment } \\
\text { elevation }\end{array}$ & 15 (22.73) & $0(0)$ & 13.84 & $.0002^{*}$ \\
\hline $\begin{array}{l}\text { T-wave } \\
\text { inversion } \\
\text { in the right } \\
\text { precordial } \\
\text { leads. }\end{array}$ & $16(24.24)$ & $1(1.7)$ & 12.317 & $.0004^{*}$ \\
\hline Bradycardia & 19 (28.79) & $0(0)$ & 18.744 & $<.0001^{*}$ \\
\hline $\begin{array}{l}\text { Prolonged } \\
\text { QTc }\end{array}$ & $9(13.64)$ & $0(0)$ & 7.128 & $.00761 *$ \\
\hline $\begin{array}{l}\text { Anti- } \\
\text { clockwise } \\
\text { rotation }\end{array}$ & $24(36.36)$ & $0(0)$ & 25.43 & $<.0001^{*}$ \\
\hline Normal ECG & $11(16.67)$ & $60(96.77)$ & 4.942 & $0.0262^{*}$ \\
\hline
\end{tabular}

Table 5: Comparison of electrocardiographic characteristics of the elderly and controls.

\begin{tabular}{|c|c|c|c|c|}
\hline \multirow{2}{*}{$\begin{array}{c}\text { Precordial } \\
\text { Lead }\end{array}$} & \multicolumn{2}{|c|}{ Frequency (\%) } & \multirow{2}{*}{$\begin{array}{c}\text { Chi- } \\
\text { Square }\end{array}$} & P-Value \\
\cline { 2 - 3 } & Elderly(N=66) & Young(N=62) & & \\
\hline V1 & $4(7 \%)$ & $0(0 \%)$ & & \\
\hline V2 & $17(29.8 \%)$ & $13(21.0 \%)$ & & 0.0007 \\
\hline V3 & $24(42.1 \%)$ & $47(75.8 \%)$ & 19.141 & \\
\hline V4 & $10(17.5 \%)$ & $2(3.2 \%)$ & & \\
\hline V5 & $2(3.5 \%)$ & $0(0 \%)$ & & \\
\hline
\end{tabular}

Electrocardiographic values of heart rate, P-wave duration, P-wave dispersion, PR interval, QRS dispersion and QTc dispersion were significantly increased in the elderly (Table 3). Electrocardiographic abnormalities were observed in $83.33 \%$ of the elderly subjects and in $3.23 \%$ of the young subjects. Electrocardiographic abnormality noted include; left ventricular hypertrophy, left atrial enlargement, left axis deviation, non specific ST segment elevation, T-wave inversion, sinus bradycardia (Table $4,5)$.

\section{Discussion}

In our well selected cohorts of apparently healthy elderly subjects significant electrocardiographic abnormalities were evident in $83 \%$ of the participants. De Bacquer, et al. found major morphological electrocardiographic changes in 5.5 per cent of a relatively younger population comprising of 47358 working individuals between 40 and 64 years of age using data derived from four large epidemiological studies performed in Belgium over a 30-year period [3]. Community -based descriptive studies similar to ours have reported high frequencies of electrocardiographic abnormalities in elderly individuals, but the overall prevalence ratings were not specified $[13,14]$. However, results from studies on electrocardiographic evaluation of elderly patients without heart disease undergoing non-cardiac procedures revealed abnormal electrocardiogram in 70 to $78.8 \%$ of patients [15-17]. The durations of P-wave, QTc as well as PR interval were all increased in the elderly subjects compared with the younger individuals. These findings may be attributed to the numerous histological and morphological changes associated with the aging myocardium. The increase in atrial dimension in the elderly reported in a number of studies would account for the observed increased P-wave duration $[8,18,19]$. This is in keeping with the finding in this study of electrocardiographic evidence of left atrial enlargement which ranked as the highest occurring electrocardiographic abnormality in $36 \%$ of the elderly. The prolonged PR, OTc, as well as bradycardia observed in the elderly may be related to age associated changes in the myocardium and conducting tissues.

Left axis deviation is the second common finding in our elderly subjects (36.36\%). Khane, et al. [13], reported same finding in $21 \%$ of the elderly. It is probably due to the anti-clockwise rotation of the heart along its own long axis and greater freedom of motion of the heart within the thorax in the elderly subject due to the anatomical changes in the older population $[13,20,21]$. It is therefore not surprising our observation of high prevalence of counter-clockwise rotation in these subjects (36.36\%). A striking observation in this study is the high prevalence of ST segment elevation and T-wave inversion in the elderly, even though none of the subjects gave any history of angina during evaluation. Several studies have shown that elderly individuals with ischaemic heart disease present with atypical symptoms and cases of silent myocardial infarction have been reported [22,23]. A 10 year longitudinal cohort study evaluating the association of silent electrocardiographic findings with coronary deaths among elderly men in three European countries (The FINE study) noted Silent electrocardiographic abnormalities of presumed severity in more than half of these elderly men, with the relative risk of coronary death ranging from around 1.5 to almost 4 or more depending upon severity and combination 
of findings [22]. In a study of middle-aged subjects without a known cardiac disease, ECG abnormalities found to possess the highest predictive value for Sudden Cardiac Death events were increased QRS duration ( $>110 \mathrm{~ms}$ ), left ventricular hypertrophy, T-wave inversion and abnormal QRST-angle [23]. However, the aging myocardium is also liable to repolarization abnormalities which may occur in the absence of any ischaemia. In summary, our study has recorded high prevalence of electrocardiographic abnormalities in asymptomatic apparently healthy elderly subjects. The implication of our findings is that cardiac diseases may present with more subtle symptoms in the elderly. Hence the need for routing evaluation with electrocardiography and other measures for early detection and intervention.

\section{Acknowledgement}

None.

\section{Conflict of Interest}

No conflict of interest.

\section{References}

1. Nash MP, Pullan AJ (2005) Challenges Facing Validation of Noninvasive Electrical Imaging of the Heart. Ann Noninvasive Electrocardiology 10(1): 73-82

2. Hiss RG, Lamb LE (1962) Electrocardiographic findings in 122,043 individuals. Circulation 25: 947-961.

3. De Bacquer D, De Backer G, Kornitzer M (2000) Prevalence of ECG findings in large population based samples of men and women. Heart 84: 625-633.

4. Pelliccia A, Culasso F, Di Paolo FM, Accettura D, Cantore R, et al. (2007) Prevalence of abnormal electrocardiograms in a large, unselected population undergoing pre-participation cardiovascular screening. Eur Heart J 28: 2006-2010.

5. Pelliccia A, Di Paolo FM, Quattrini FM, Basso C, Culasso F, et al. (2008) Outcomes in athletes with marked ECG repolarization abnormalities. N Engl J Med 358: 152-161.

6. Hingorani P, Natekar M, Deshmukh S, Karnad DR, Kothari S, et al (2012) Morphological abnormalities in baseline ECGs in healthy normal volunteers participating in phase I studies. Indian J Med Res 135: 322330.

7. Fleg JL, Kennedy HL (1982) Cardiac arrhythmias in a healthy elderly population: Detection by 24-hour ambulatory electrocardiography. Chest 81: 302-307.

8. Kannel WB, Abbot RD, Savage DD, McNamara PM (1983) Coronary heart disease and atrial fibrillation: The Framingham Study. Am Heart J 106 389-396.
9. Ganong WF (1989) Review of medical physiology. $14^{\text {th }}$ Edition, Appleton and Lange. California Pp. 236-546.

10. David M Mirvis, Ary L Goldberger (2005) Electrocardiography. In: 26. Zipes D, Libby P, Bonow R, Braunwald E (Eds.), Braunwald's heart disease, A textbook of cardiovascular medicine. 7th ed. Philadelphia, Pa: WB Saunders Co, pp. 107-152.

11. Bazett $H$ (1920) An analysis of time relations of electrocardiograms. Heart 7: 353-370

12. Surawicz B, Parikh SR (2002) Prevalence of Male and Female Patterns of Early Ventricular Repolarization in the Normal ECG of Males and Females From Childhood to Old Age. J Am Coll Cardiol 40: 1870-1876.

13. Khane RS, Surdi AD, Bhatkar RS (2011) Changes in ECG pattern with advancing age. Journal of Basic and Clinical Physiology and Pharmacology 22(4): 97-101.

14. Ulla Molander, Debashish Kumar Dey, Valter Sundh, Bertil Steen (2003) ECG abnormalities in the elderly: prevalence, time and generation trends and association with mortality. Aging Clin Exp Res 15(6): 488-493.

15. Khane RS, Surdi AD, Bhatkar RS (2011) Changes in ECG pattern with advancing age. Journal of Basic and Clinical Physiology and Pharmacology 22(4): 97-101.

16. Liu LL, Dzankic S, Leung JM (2002) Preoperative electrocardiogram abnormalities do not predict postoperative cardiac complications in geriatric surgical patients. J Am Geriatr Soc 50: 1186-1191.

17. Seymour DG, Pringle R, MacLennan WJ (1983) The role of the routine pre-operative electrocardiogram in the elderly surgical patient. Age Ageing 12: 97-104.

18. Aurigemma GP, Gottdiener JS, Arnold AM, Chinali M, Hill JC, et al. (2009) Left atrial volume and geometry in healthy aging: the Cardiovascular Health Study. Circ Cardiovasc Imaging 2(4): 282-289.

19. Tsang TS, Barnes ME, Bailey KR, Leibson CL, Montgomery SC, et al (2001) Left atrial volume: important risk marker of incident atrial fibrillation in 1655 older men and women. Mayo Clin Proc 6: 467-475.

20. Mihalick MJ, Fisch C (1974) Electrocardiographic findings in the aged. Am Heart J 87: 117-128.

21. Olbrich 0, Woodford W (1953) The effect of body position on the precordial electrocardiogram in young and aged subject. J Gerontol 8: $56-62$.

22. Alessandro Menotti, Ina Mulder, Daan Kromhout, Aulikki Nissinen, Edith JM, et al. (2001) The association of silent electrocardiographic findings with coronary deaths among elderly men in three European countries. The FINE study., Acta Cardiologica 56(1): 27-36.

23. Terho HK, Tikkanen JT, Kenttä TV, Junttila JM, Aro AL, et al. (2018) Electrocardiogramas a predictor of sudden cardiac death inmiddle-aged subjects without a known cardiac disease. IJC Heart \& Vasculature 20 50-55. 